\title{
Variable structural controls through time in the Southern Central Andes $\left(\sim 36^{\circ} \mathrm{S}\right)$
}

\author{
Darío L. Orts ${ }^{1}$, Andrés Folguera ${ }^{1}$, Mario Giménez ${ }^{2}$, Víctor A. Ramos ${ }^{1}$
}

\author{
${ }^{1}$ Laboratorio de Tectónica Andina, Instituto de Estudios Andinos 'Don Pablo Groeber' (IDEAN), Universidad de Buenos Aires- \\ CONICET, Facultad de Ciencias Exactas y Naturales, Pabellón II, Ciudad Universitaria, Buenos Aires, Argentina, C1428EGA. \\ dlorts@gl.fcen.uba.ar; folguera@gl.fcen.uba.ar; andes@gl.fcen.uba.ar \\ ${ }^{2}$ Instituto Geofísico-Sismológico 'Ing. F.S. Volponi’ (IGSV). Universidad Nacional de San Juan-CONICET, Facultad de Ciencias \\ Exactas, Físicas y Naturales, Meglioli 1160 Sur, Rivadavia, Provincia de San Juan, Argentina, CP 5400. \\ mgimenez@unsj-cuim.edu.ar
}

\begin{abstract}
The Southern Central Andes at $36^{\circ} \mathrm{S}$ have been recognized as an orogenic belt where contraction, accommodated mainly by basement structures, is associated with the inversion of a Late Triassic-Early Jurassic extensional detachment. Based on a structural cross-section, constrained by field data, 2D seismic and bore-hole information, and the processing of Bouger anomalies, we propose a polyphasic tectonic evolution. In the westernmost sector, along the axis of the Cordillera, NW to NNW basement structures were inverted, being a first order control in the generation of frontal narrow $\mathrm{N}$-trending thin-skinned belts. This slip transfer is controlled by the Late Jurassic main detachment. These structures have low gravity anomalies that cross obliquely the main Andean trend. East of this inversion domain, beneath the frontal thin-skinned belts, seismic information reveals that Late Triassic wedge-like depocenters did not experience substantial inversion. To the east double-vergent basement blocks define the Andean emergent orogenic front at these latitudes. These contractional structures truncate gravity anomalies defined by basement discontinuities, indicating that they are not related to tectonic inversion, in contraposition to the westernmost domain. Two contractional phases were distinguished. The oldest is Late Cretaceous in age, as inferred from onlap relations in Upper Cretaceous strata identified in seismic lines. These successions have a maximum age of $97 \mathrm{Ma}$ as inferred by U-Pb in detrital zircons published in previous studies in the area. Contrastingly, the easternmost sector was mainly deformed in Late Miocene times as inferred from less than 18 Ma old synorogenic deposits. Moreover, contractional mechanisms varied through time for each specific sector. While Late Cretaceous contractional tectonics was generated by tectonic inversion and subordinate thin-skinned deformation, it is proposed that Late Miocene deformation was controlled mainly by brittle-ductile transitions at the upper crust with no major influence of previous structures. This fact can be explained by a higher thermal flux achieved in the retroarc area in the last 17 Ma due to the eastward arc expansion during a shallow subduction regime.
\end{abstract}


RESUMEN. Controles estructurales variables en el tiempo en los Andes Centrales Australes ( 36º $)$. Los Andes Centrales Australes a los $36^{\circ} \mathrm{S}$ han sido reconocidos como una faja orogénica en donde la contracción, principalmente acomodada por estructuras de basamento, está asociada a la inversión de un sistema extensional del Triásico Tardío-Jurásico Temprano. Basados en una sección estructural, construida a partir de datos de campo, líneas sísmicas 2D, datos de pozo y el procesamiento de anomalías de Bouger, proponemos una evolución tectónica polifásica. En el sector occidental, a lo largo del eje cordillerano, estructuras de basamento con orientación NW a NNW fueron invertidas actuando como un control de primer orden en la generación de fajas frontales de piel fina angostas y de orientación norte. La transferencia de acortamiento es controlada por el despegue principal del Jurásico Tardío. Estas estructuras coinciden con bajos de anomalías gravimétricas que cortan de manera oblicua al eje estructural andino. Hacia el este del dominio de inversión, por debajo de las fajas frontales de deformación de piel fina, la información sísmica revela depocentros cuneiformes del Triásico Tardío que no experimentaron una inversión significativa. Hacia el este, bloques de basamento doble-vergentes definen el frente orogénico emergente Andino a estas latitudes. Estas estructuras contraccionales truncan anomalías gravimétricas definidas por anisotropías de basamento, indicando que no están relacionadas a inversión tectónica, a diferencia del dominio occidental. Fueron distinguidas dos fases contraccionales. La más antigua es de edad cretácica tardía, inferida a partir de relaciones de 'onlap' en los estratos del Cretácico Superior identificados en perfiles sísmicos. Estas secuencias tienen una edad máxima de $97 \mathrm{Ma}$, fecha inferida a partir de circones detríticos U-Pb publicados en estudios previos en el área. En contraste, el sector oriental fue deformado principalmente en el Mioceno Tardío, dato inferido por estratos sinorogénicos más jóvenes que 18 Ma. Además, los mecanismos estructurales variaron temporalmente en cada sector en particular. Mientras que la tectónica contraccional fue generada por inversión tectónica y con deformación de piel fina subordinada, se propone que la deformación del Mioceno Tardío fue controlada principalmente por transiciones frágiles-dúctiles en la corteza superior sin mayor influencia de estructuras previas. Este hecho puede ser explicado por un flujo termal elevado que afectó al retroarco en los últimos 17 Ma debido a una expasión oriental del arco durante un régimen de subducción somera.

Palabras clave: Andes Centrales, Faja plegada y corrida de Malargüe, Inversión tectónica, Transiciones frágiles-dúctiles, Frente orogénico, Cuenca de antepaís, Argentina.

\section{Introduction}

The eastern slope of the southern Central Andes between $34^{\circ} 15^{\prime}$ and $38^{\circ} \mathrm{S}$ correspond to the Malargüe fold and thrust belt (Malargüe FTB). This segment is associated with a normal subduction regime, showing well developed arc magmatism hosted at the drainage divide area and western slope of the Andes (Stern, 2004; Kay et al., 2005). However, this regime would have been established only since 5 Ma after an extinguished shallow subduction regime in the area (Kay et al., 2006). At $17 \mathrm{Ma}$, rear arc-magmatism expanded-migrated over the eastern slope of the Andes (Spagnuolo et al., 2008, 2011) and then at approximately 14-7 Ma jumped to the foreland zone, east of the Malargüe FTB. This shallow subduction regime was first established since the identification of arc-derived magmas emplaced more than $500 \mathrm{~km}$ from the trench in the foreland area (Bermúdez et al., 1993). Its time span was determined from 14 to 4 Ma based on K-Ar dating of those eastern mesosilicic centers (Spagnuolo et al., 2008, 2011; Litvak et al., 2008). Coincidentally, the last contractional episode that affected the area occurred between 17 and $8 \mathrm{Ma}$ at the time of east- ward arc expansion (Kay et al., 2006; Spagnuolo et al., 2008; Litvak et al., 2008).

During the last decades long controversy has existed around the mechanisms that were linked to the construction of the eastern slope of the Andes at these latitudes. Then, its construction has been connected to different processes, among which $\mathbf{i}$. the absolute displacement of the South American plate against the Chilean trench was considered the main controlling variable (Somoza, 1998; Somoza and Zaffarana, 2008); while other complementary theories invoked; ii. variable thermal crustal properties in order to favor its lateral collapse (James and Sacks, 1999). Structural mechanisms have been usually regarded as a second order control: Even though the role of tectonic inversion of TriassicEarly Jurassic rift systems (Fig. 1) has been invoked as an important control in the development of thrust sheets in the area (Manceda and Figueroa, 1995; Zapata et al., 1999), other studies indicate that primary basement faults, associated with the development of brittle-ductile transitions, are the dominant mechanisms that accommodated shortening (Ramos et al., 2002; Giambiagi et al., 2009; Turienzo, 2009, 2010). 


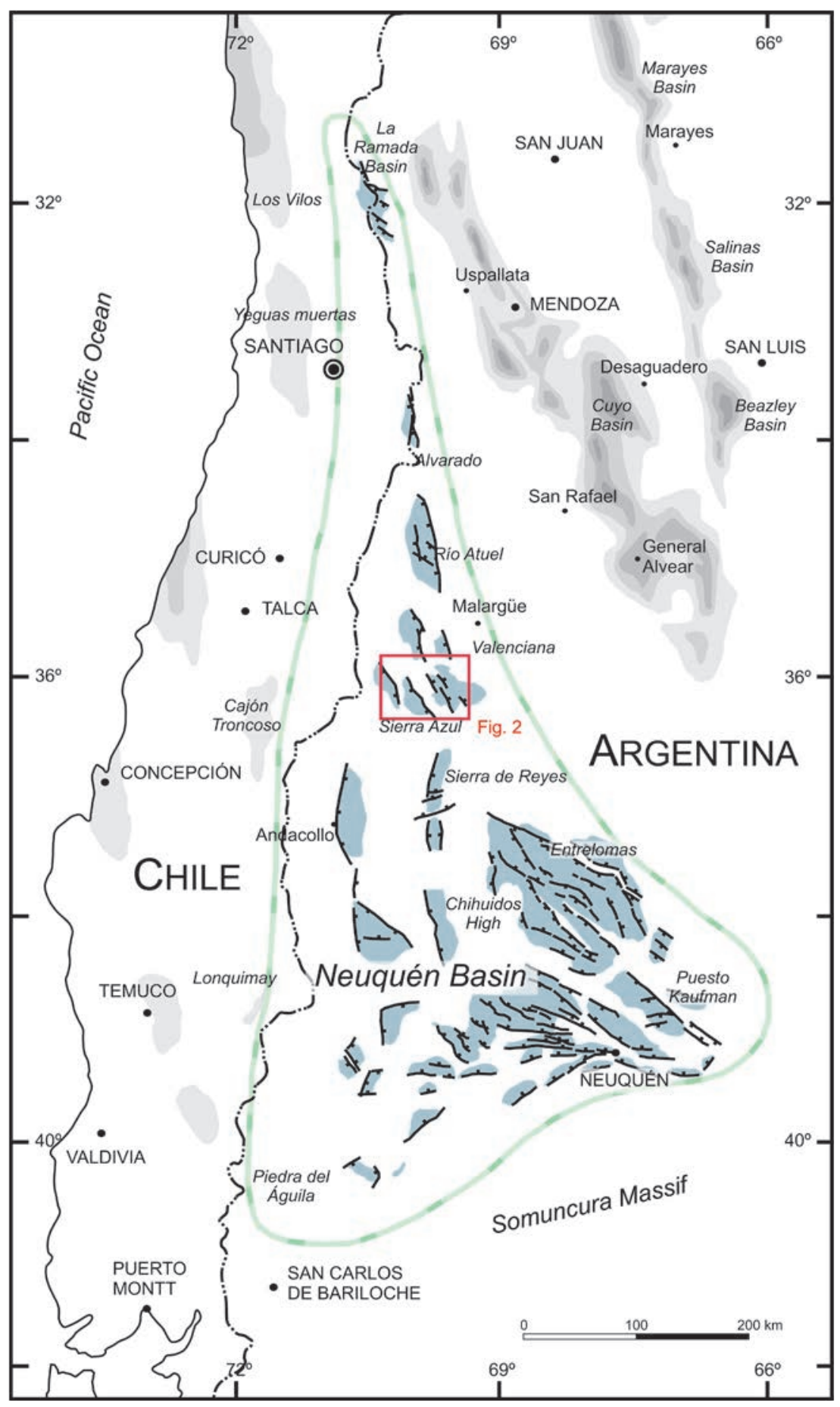

FIG. 1. Location map of the study zone and Late Triassic-Lower Jurassic extensional depocenters in the Neuquén basin and adjacent rift systems. Note the study area located at the Sierra Azul rift system interpreted as a series of NW trending structures. Rift systems associated with the Neuquén basin are indicated in dark blue together with main extensional structures, whereas rift systems outside this embayment are indicated in light grey in which different tonalities give a qualitative idea of variable thicknesses in the western slope of the Andes and further north (modified from Charrier et al., 2007; Mosquera and Ramos, 2006; Mpodozis and Ramos, 2008; Bechis, 2009). 
This work, through a detailed description of the surficial geology plus the analyses of seismic borehole information and gravimetric data registered in the eastern slope of the Andes at $35.5^{\circ}-36.5^{\circ} \mathrm{S}$, will attempt to discuss and address these topics. Thus, from the description of the different contractional mechanisms, a chronology of deformation through the orogenic wedge will be proposed.

\section{Geological setting}

The oldest outcrops in the study area through the eastern slope of the Andes (Fig. 1) are PermianTriassic rhyolitic-dacitic rocks of the Choiyoi Group interbedded with clastic successions (Fig. 2). The Choiyoi Group together with unexposed older metamorphic, volcanic and plutonic rocks constitutes the crystalline basement of this deformational belt. During the Late Triassic to Early Jurassic the Gondwana margin underwent tectonic extension allowing the accumulation of marine and continental deposits behind and next the arc zone (Fig. 2) (Manceda and Figueroa, 1995) forming isolated depocentres. These were linked to the reactivation of previous anisotropies (Fig. 1) inherited from Paleozoic amalgamation in the area (Ramos, 1989; Mpodozis and Ramos, 2008). These synrift deposits are covered by Middle Jurassic to Lower Cretaceous platform successions deposited during a thermal subsident stage (Fig. 2). The inception of a compressional regime from Late Cretaceous times (Tunik et al., 2010) coincident with a major tectonic plate reorganization (Somoza, 1998; Somoza and Zaffarana, 2008) controlled the Late Cretaceous to Tertiary paleogeography.

Late Cretaceous non marine successions (Fig. 2) exhibit a synorogenic nature defined by i. the presence of syngrowth strata (Orts and Ramos, 2006); ii. condensed sequences on top of major contractional structures (Bettini et al., 1978; Galarza et al., 2009), together with iii. the occurrence of populations of Early Jurassic-Late Cretaceous detrital zircons, absent in lower sections, derived from the main Andes to the west, associated with a contemporaneous arc-related source (Tunik et al., 2010). From Latest Cretaceous to Paleocene times the Andean front was flooded by the first Atlantic transgression. This was related to the deposition of marine successions of the basal part of the Malargüe Group (Fig. 2) through a narrow corridor potentially associated with lithospheric flexure under orogenic loading. In the study area, spare outcrops of the Malargüe Group can be found from the orogenic front (Fig. 3a) to the westernmost sector, next to the drainage divide area, implying that

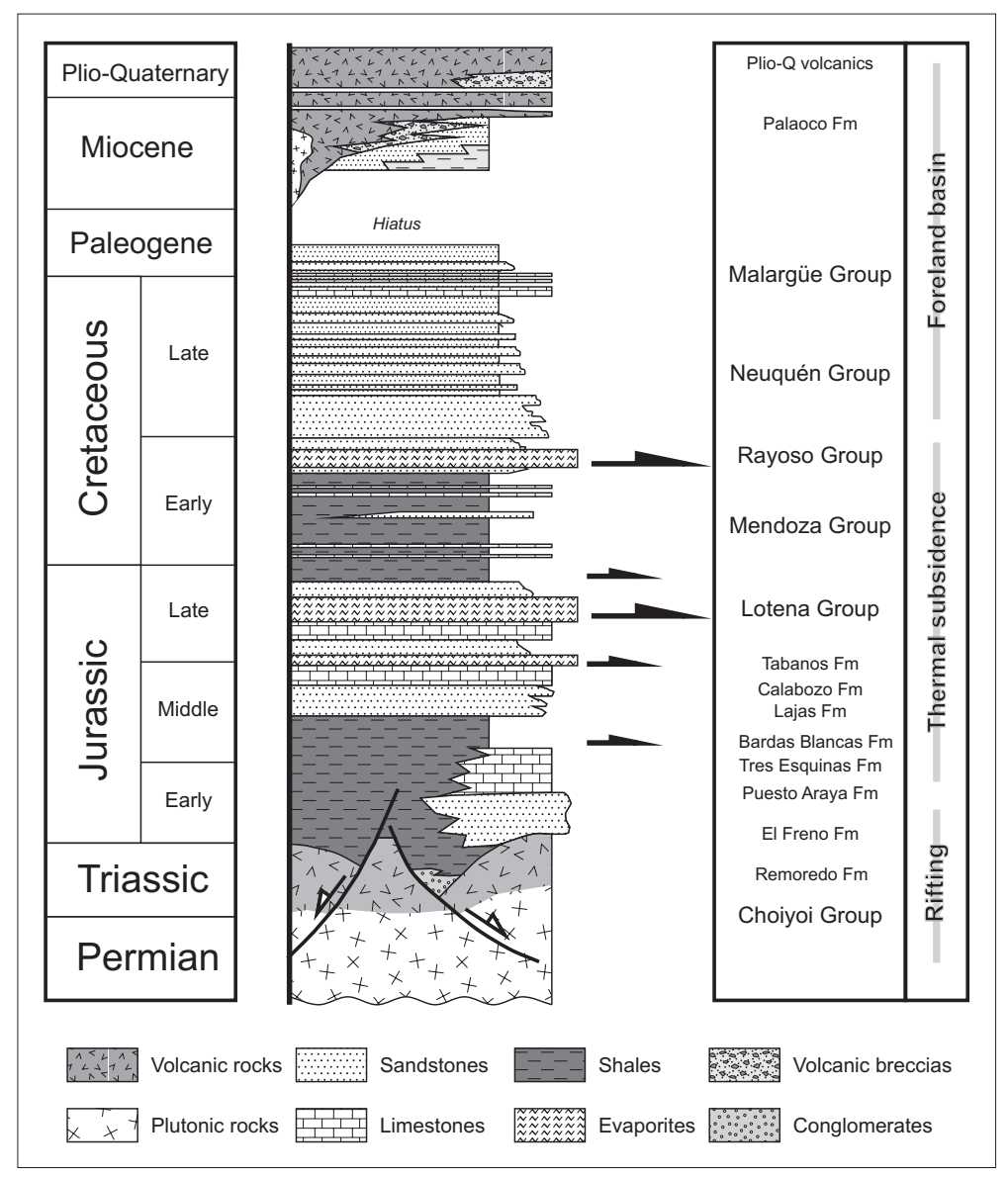

FIG. 2. Generalized stratigraphic column at the Malargüe FTB $\left(\sim 36^{\circ} \mathrm{S}\right)$, showing main lithostratigraphic units and principal detachment levels. 


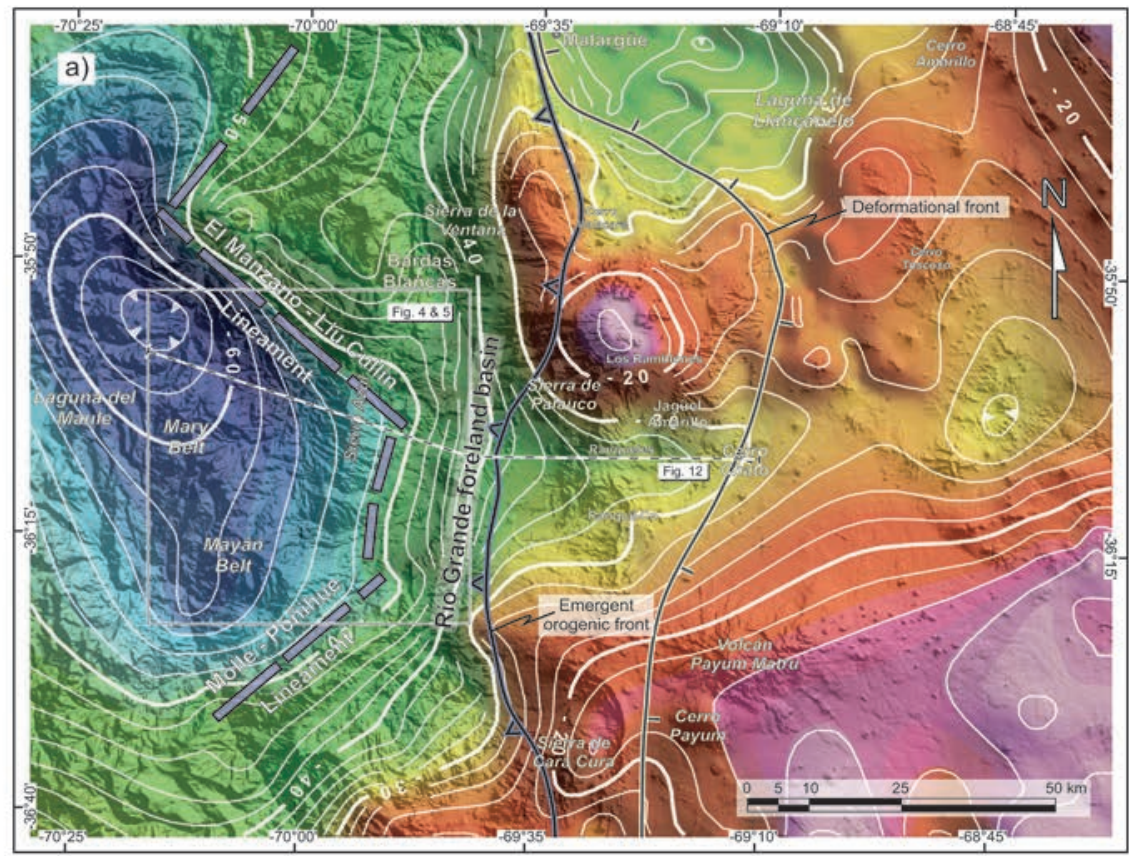

$\begin{array}{llllllllll}-61 & -54 & -49 & -42 & -35 & -29 & -26 & -23 & -18 & -14 \mathrm{mGal}\end{array}$

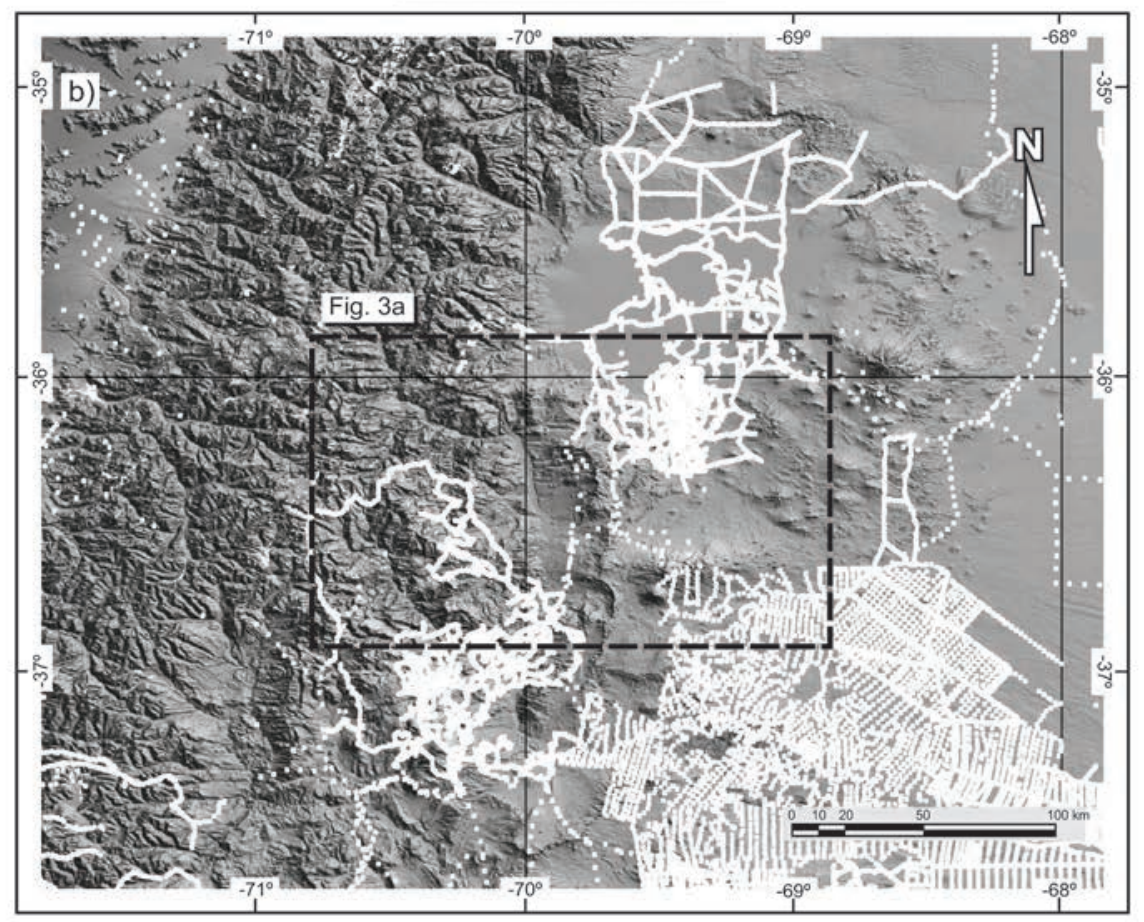

FIG. 3. a. Shaded digital elevation model with residual gravity anomaly contours in mGals draped on it. Main structural lineaments are drawn based on main gravity gradients (dashed bold lines). These are interpreted as boundaries of inner-western Late TriassicEarly Jurassic extensional depocenters. Note a NW-trending low eastwardly controlled by the El Manzano-Liú Cullín and Molle-Poñihue lineaments, obliquely oriented respect to the main Andean trend. Deformational and emergent orogenic fronts are indicated. Location of structural cross section (figure 12) is indicated; b. Data set used in this study. 
an important section of the eastern Andean slope at these latitudes was constructed after Paleocene times.

An angular unconformity separates basal strata of the Malargüe Group from the upper Late Oligocene volcaniclastic piles of the Palaoco Formation. These have been dated at 27-19 Ma (Nullo et al., 2002; Kay et al., 2006). This unconformity indicates a major mountain building episode previous to $\sim 30 \mathrm{Ma}$. The Palaoco Formation occupies the area interposed between the orogenic front and the foreland area. To the west, the Cura Mallín basin, a coeval sequence to these successions (Suárez and Emparán, 1995; Jordan et al., 2001; Radic et al., 2002; Radic, 2010) has been related to extensional relaxation of the hinterland zone, at the western slope of the Andes, beyond the scope of this work.

Late Miocene times correspond again to a major contractional stage in the Southern Central Andes, constrained by fission track data at the western slope of the Andes (Spikings et al., 2008) and by the development of a foreland basin (Río Grande Foreland Basin) developed from 18 to $8 \mathrm{Ma}$ associated with the orogenic front at the eastern side of the Andes (Fig. 3) (Silvestro and Atencio, 2009).

\section{Data and methods}

Cross sections have been done combining geologi$\mathrm{cal}$ and geophysical data. Geophysical data comprises gravimetric (Fig. 3), 2D seismic and borehole data. The compilation of structural data from $\mathbf{i}$. new field surveys and ii. a series of recent unpublished geological theses in the Malargüe FTB (Quintana, 2008; Kozlowski, 2008 and Orts, 2009), combined with iii. precedent geological studies in the area (Bettini et al., 1979; Kozlowski et al., 1993; Manceda and Figueroa, 1995; Nocioni, 1996; Dimieri, 1997) and iv. unpublished reports of YPF S.A., allowed the construction of a new map that reflects the surface geology (Fig. 4).

Gravity data consist of 2,700 new measurements which were added to the database of the 'Ing. F.S. Volponi' Geophysic and Seismologic Institute of the National University of San Juan yielding a total of 4,500 gravimetric values for the study area (Fig. 3b), all of them linked in the System IGSN1971. Classic techniques were used to calculate the anomalies (Blakely, 1995). The normal gradient of 0.3086 $\mathrm{mGal} / \mathrm{m}$ was used for the free air correction, and the density of $2.67 \mathrm{~g} / \mathrm{cm}^{3}$ for the Bouguer correction
(Hinze, 2003). Thereafter, the gravimetric observations were reduced topographically, by means of the Hayford zones up to the circular zones with $167 \mathrm{~km}$ of diameter using the Digital Elevation Model obtained from the Shuttle Radar Topography Mission (SRTM) of the U.S. Geological Survey and NASA, based on techniques that combine the algorithms developed by Kane (1962) and Nagy (1966). The gravity nets were gridded using the minimum curvature method, which is usually sufficient to regularize field points measured at unevenly spaced stations on a topographic surface (Briggs, 1974). Finally, different filtering techniques were applied to the gravimetric field such as upward continuation analyses performed at different heights. Then a map of the Bouguer residual anomaly was obtained (Fig. 3a) from the resulting difference between the observed anomaly and the upward continuation extended up to $40 \mathrm{~km}$.

The subsurface information consists of a series of 2D reflection seismic lines acquired by BRIDAS S.A.P.I.C. in the middle 90's and later reprocessed by YPF S.A. together with borehole data at the eastern slope of sierra Azul and Rio Grande basin.

\section{Subsurface regional structure from gravity data}

The processing of gravity data constituted the isolation of short wave-length anomalies that represent mostly upper-crustal discontinuities, related to density contrasts, produced by a complex basement geometry. The map of gravimetric residuals shows values ranging from -65 to $-10 \mathrm{mGal}$ (Fig. 3a). Here two major zones can be identified separated by the orogenic front: i. the highest values (lowest in modulus), corresponding to the first individualized sector, are located at the eastern foreland area, east of the orogenic front (Fig. 3a). These anomalies are associated with maximum values describing equidimensional geometries, located in the Sierra de Palaoco area. To the south of this zone a broad gravity gradient can be identified aligned with the Sierra de Cara Cura and Payún Matrú volcanic centers showing an ENE trend of smooth contour lines (Fig. 3a). ii.The second sector corresponds to the eastern Andean slope where the study area is located in the emergent orogenic wedge. This is characterized by a wide zone of a NNW-oriented minimum that shows linear edges identified by their high gradients. These oblique lineaments match important morphostructural features such as the 


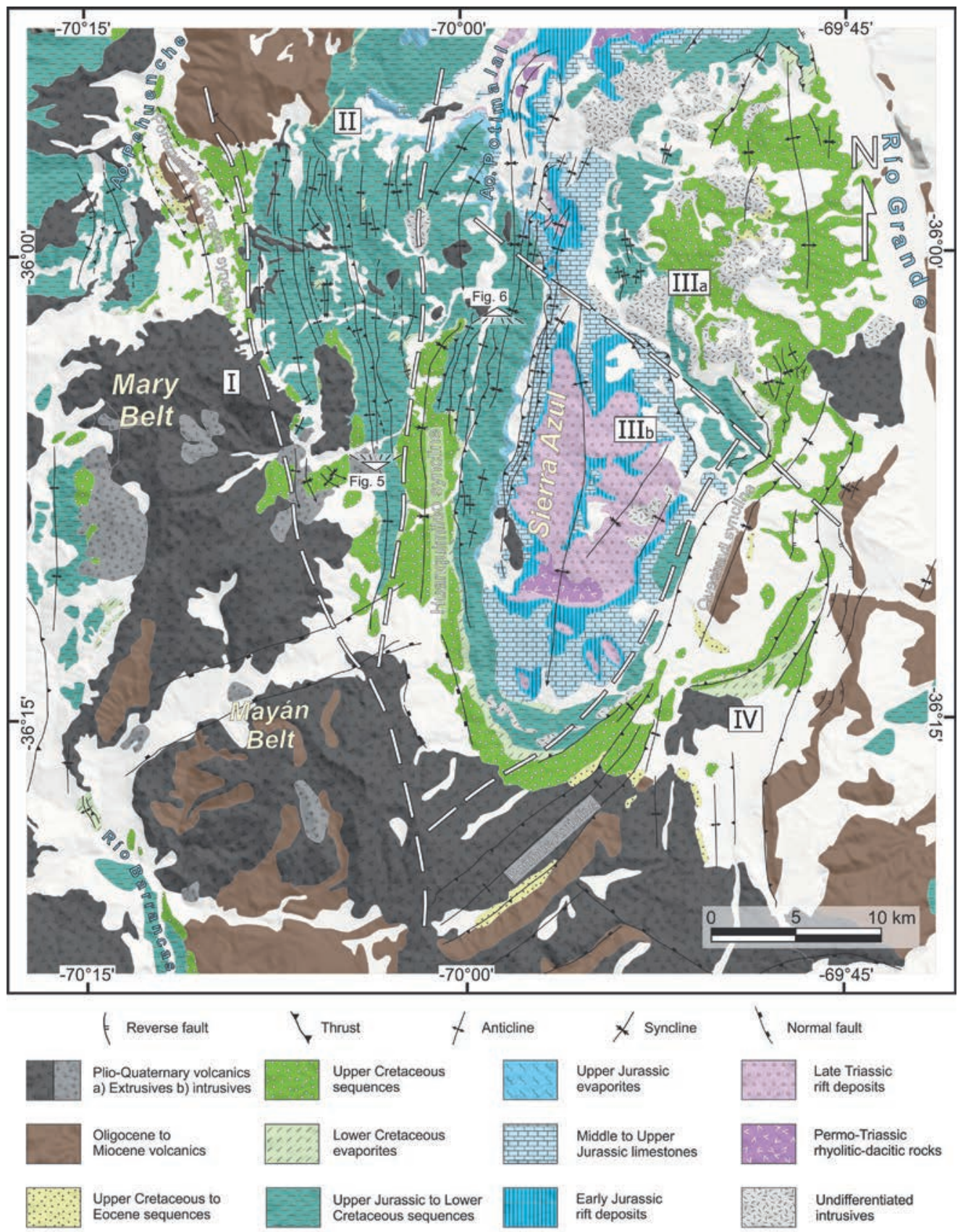

FIG. 4. Geological map of the westernmost part of Malargüe FTB and Sierra Azul adjacent zone. For location see figure 3. Four areas (I, II, III, IV) with particular geological features can be distinguished, involving specific sedimentary units deformed at surface and unique structural characteristics: i. a westernmost sector (upper left corner), where structure is NNW-oriented and associated at surface with Late Jurassic to Late Cretaceous sequences corresponding to the Neuquén basin sag facies and initial development of the foreland basin (see text for further details); ii. to the east, a narrower N-oriented structural system developed up to the western Sierra Azul western slope; iii. a third domain, the Sierra Azul anticline exposes the deepest terms of the Neuquén basin at these latitudes up to the Permian-Late Triassic, constituting the initial graben infill. This system is associated with a Neogene foreland basin to the east (Silvestro and Atencio, 2009); iv. Finally, a fourth area can be distinguished south of Sierra Azul anticline plunge, characterized by NE-trending thrusts and folds. Here, widespread 17 Ma Miocene volcanic arc rocks (Spagnuolo et al., 2008, 2011), cover vast parts of the region. 
Sierra Azul anticline with a $\sim \mathrm{N}$ trend and the NW El Manzano-Liu Cullín lineament (Yagupsky et al., 2008). Along the El Manzano-Liu Cullín lineament, major thickness variations in Late Triassic to Early Jurassic deposits were identified, implying that this feature constituted an important discontinuity oriented obliquely with respect to the main Andean trend. The Molle-Poñihue NE lineament divides this area through its southern edge (Fig. 3a). The result yields a series of rhomboedric features associated with important gravity gradients potentially connected to steps in basement geometry that segments the fold and thrust belt.

\section{Study area in the Malargüe FTB from surface analyses}

The study zone is located entirely west of the orogenic front and over the wedge top sector of the Late Miocene foreland basin (Fig. 3). It comprises from the Sierra Azul in the east, adjacent to the Late Miocene Río Grande foreland basin (Figs. 3 and 4), to the drainage divide area. It is characterized by excellent outcrops where contrasting erosional levels and different deformational styles show different domains. These involve from Permian-Triassic rocks corresponding to the crystalline basement, to Mesozoic deposits of the Neuquén basin, and a Neogene-Quaternary volcanic cover.

Four zones, based on these contrasting levels of erosion and particular structural patterns can be recognized: Zone I (Fig. 4) located at the westernmost part is characterized by the exposure of Early to Middle Jurassic packages that were strongly deformed showing asymmetric anticlines with intermediate wave-lengths ( $\sim-10 \mathrm{~km})$ at surface. The easternmost structure along this NW-trending contractional belt involves the Portezuelos Colorados syncline (Fig. 4) whose core is formed by relatively younger successions up to Cretaceous-Oligocene deposits.

Zone II (Fig. 4) comprehends a series of Ntrending narrow folds with a wave-length between 1 and $2.5 \mathrm{~km}$, associated with east-verging thrusts that expose Late Jurassic to Late Cretaceous beds (Figs. 4 and 5). Folds are symmetric and extend for about 10-15 km along strike (Fig. 4).

Zone III (Fig. 4) is located in coincidence with the Sierra Azul range, on the eastern study area (Fig. 4). In this domain the structures can be described as forming a double-verging system, whose western section corresponds to a series of backthrusts that exposes up to Late Triassic beds constructing the western slope of the Sierra Azul (Fig. 6). These backthrusts expose thick sections of Late Triassic packages on top of the previously described domain, determining a triangle zone in the arroyo Potimalal area (Fig. 4).

The eastern section along this area is formed by a series of east-verging thrusts that are affecting at surface younger successions from Late Cretaceous to Miocene in age, corresponding to the lower terms of the Río Grande foreland basin. This third sector is divided by the El Manzano-Liu Cullín lineament (Fig. 2) in a northern (IIIa; Fig. 4) and southern subsector (IIIb; Fig. 4) respectively based on their contrasting structure in map view. While, the southern subsector is characterized by $\mathrm{N}$-trending elongated folds and thrusts and exposes thick columns of Triassic beds, the northern half is formed by contractional structures more discontinuous and spare, exhuming thinner Late Triassic rocks.

Southeast of Sierra Azul anticline, a fourth structural domain (IV; Fig. 4) is represented by a series of NE structures of relatively long wave-length $(\sim 5-8 \mathrm{~km})$. This zone is related to a much shallower level of erosion from the Late Cretaceous to Late Miocene. Dominant vergences are to the SE, with the exception of two backthrusts that exhume the eastern flanks of the Quechuvil syncline and Poñihue anticline (Fig. 4).

\section{Surficial structure compared to gravity data}

Particular domains depicted in figure 4 keep a strong relationship to the processed residual gravity anomalies shown in figure 3a. Distinctive gravity features such as high gradients, orientation of isogals, location of gravity highs and lows maintain a clear relationship to each identified structural domain. The first differentiated domain (I; Fig. 4) can be related to a pronounced gravity minimum, being the lowest values in the entire area (Fig. 7). This minimum can be tracked to the south through a NNW trend aligned with the Mary and Mayán belts, up to the Río Barrancas valley (Fig. 7). This negative anomaly coincides with an area characterized by a deformed sedimentary cover through NNW oriented folds and thrusts of intermediate wave-length.

The second distinctive domain in the area (II; Fig. 4 ) is located immediately eastward of the previously 


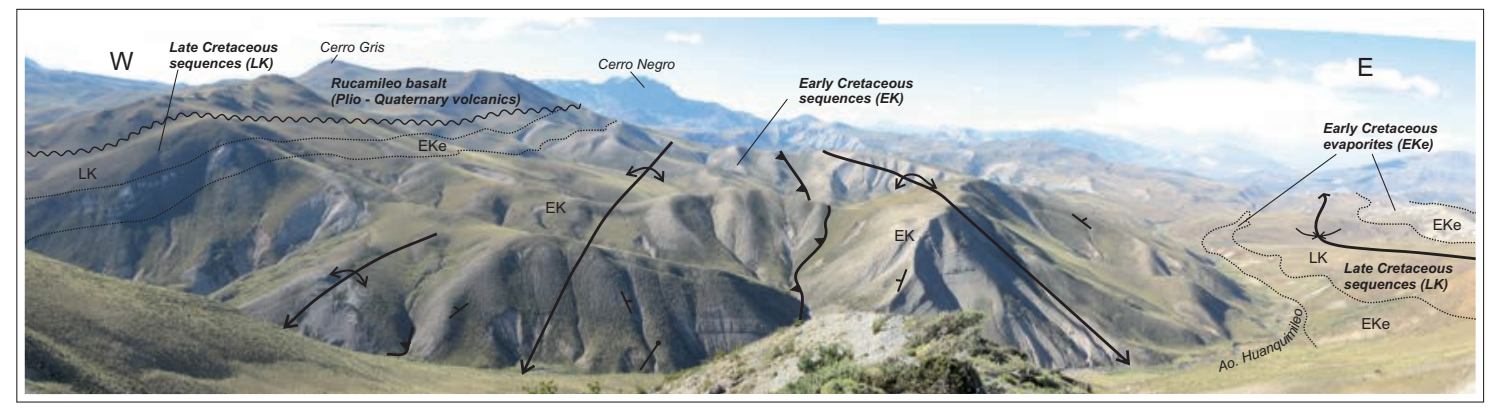

FIG. 5. Inner-western sector (zone II in figure 4) of the Malargüe fold and thrust belt west of the Sierra Azul (location in figure 4). Note that the structure at this sector is represented by narrow anticlines and short wave-length stacked thrust sheets that are exhuming Early Cretaceous sequences. The discontinuous Late Cretaceous outcrops are interpreted as remnants of a cannibalized foreland basin (see text for further details). EK: Early Cretaceous limestones and shales of Mendoza Group; EKe: Early Cretaceous evaporites of Rayoso Group; LK: Late Cretaceous shales and sandstones of Neuquén Group.

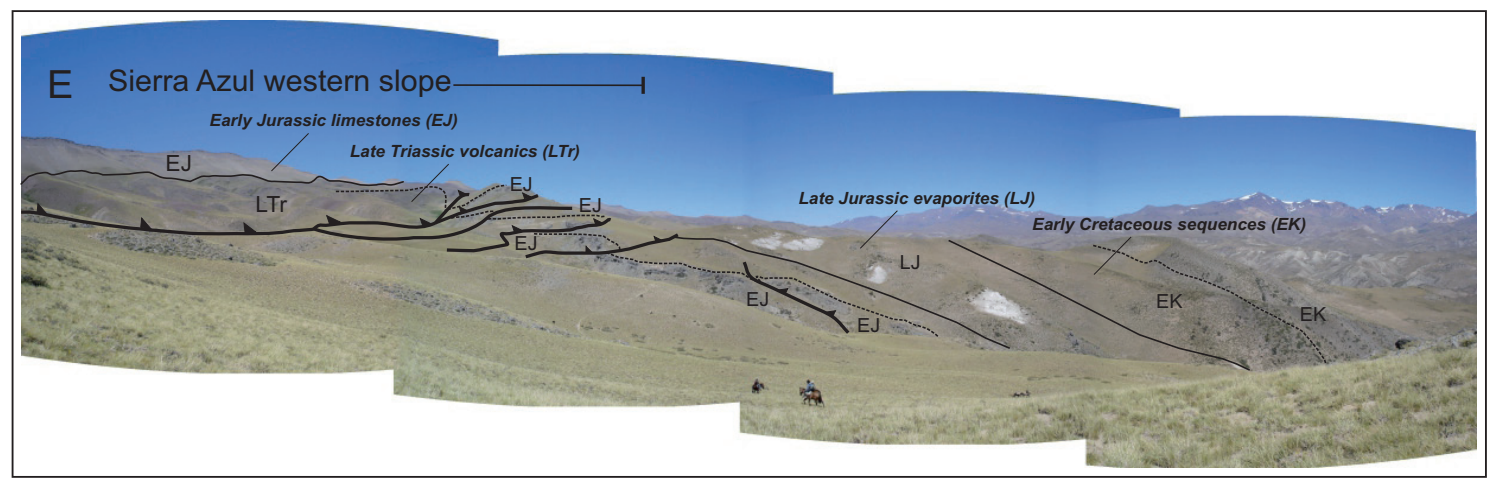

FIG. 6. Western flank of Sierra Azul anticline showing a series of backthrusts that form a triangular zone with respect to the previous east-verging fan of thrusts depicted in figure 5 (inner sector of FTB)(location in figure 4). Note that Late Triassic to Early Cretaceous sequences are exposed at the core of the anticline exhumed by the fan of backthrusts. LTr: Late Triassic continental fluvial and volcaniclastic deposits of Remoredo Formation; EJ: Early Jurassic shales and sandstones of Cuyo Group; LJ: Late Jurassic evaporites of Lotena Group; EK: Early Cretaceous limestones and shales of Mendoza Group.

described sector. It presents a series of N-trending narrow anticlines and east-verging thrusts that coincide with the orientation of isogals in this sector (Fig. 5). These isogal countours deviate to the north in a transition zone, paralleling the El Manzano-Liu Cullín lineament into the described sector IIIa. Here, the N-oriented structures are oblique respect to the NW isogals.

The Sierra Azul anticline as a whole, is the most prominent structural feature in the study area, and coincides with two contrasting gravimetric domains, coincident with the differentiated IIIa and IIIb structural domains respectively. These two subsectors are divided by the El Manzano-Liu Cullín lineament: i. a northern domain (IIIa, Figs. 4 and 7) where isogal contours abruptly deviate and do not follow the general NNE structural trend; and ii. a southern domain where isogals are perfectly parallel to exposed NNE structure. To the south isogals deviate from NNE direction through the IIIb field to NE into IV structural domain (Figs. 4 and 7), where structures are parallel to the anomaly contours.

\section{Description of contractional geometry from seismic information}

Three 2D reflection seismic lines (see figure 7 , for location) helped interpreting mapped structures 


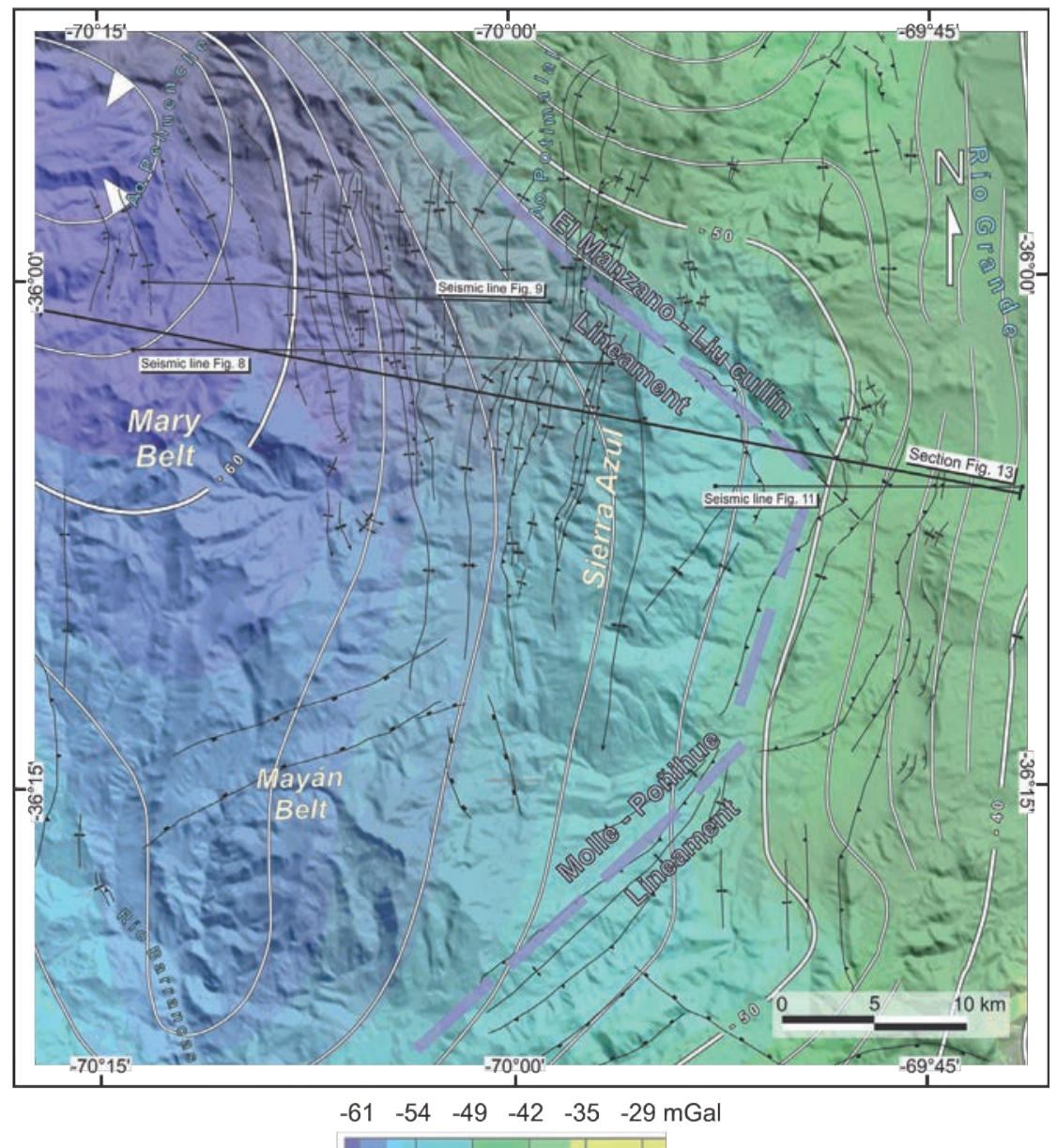

FIG. 7. Residual gravity anomalies in mGals in the study area at the Malargüe fold and thrust belt and its relation to mapped structure (see figure 3 for location). The four areas distinguished in figure 4 maintain particular relationships to gravity anomalies; from west to east: i. in the westernmost sector (upper left corner) intermediate wave-length structures, NNW-oriented, are parallel to the main axis of the gravimetric minimum depicted in figure 3; ii. immediately to the east the series of narrower $\mathrm{N}$-trending anticlines and thrusts are parallel to the isogal contours; iii. even further to the east, contours at the Sierra Azul mountain system, do not follow surficial structure at its northern part while; iv. to the south of the El Manzano-Liu Cullín lineament they are parallel.

at depth. The seismic line displayed in figure 8 is a migrated reflection survey that was recorded at the hinterland zone next to the drainage divide area. This constitutes one of the few surveys for the entire southern Central Andes over the eastern Andean slope. This subsurface information is located next to the drainage divide area, being most of the current seismic data concentrated around the orogenic front and foreland areas further to the east. Underground geometry can be directly matched to the well exposed surficial structures in the hinterland zone (zones I, II, IIIb in figure 4).
Even though noise is relatively important in this survey, some key levels can be clearly recognized and assigned to the two evaporitic units present in the deposits of the Neuquén basin due to their high reflectivity. From west to east three sectors can be recognized along the seismic section of figure 8: i. A broad syncline, revealed by long-wave folding of Lower Cretaceous evaporites. Beneath, the Jurassic section and underlying stratified packages point to the presence of Upper Triassic sequences of diffuse geometry. To the east, ii. an intermediate sector is characterized by east-verging anticlines and thrusts 


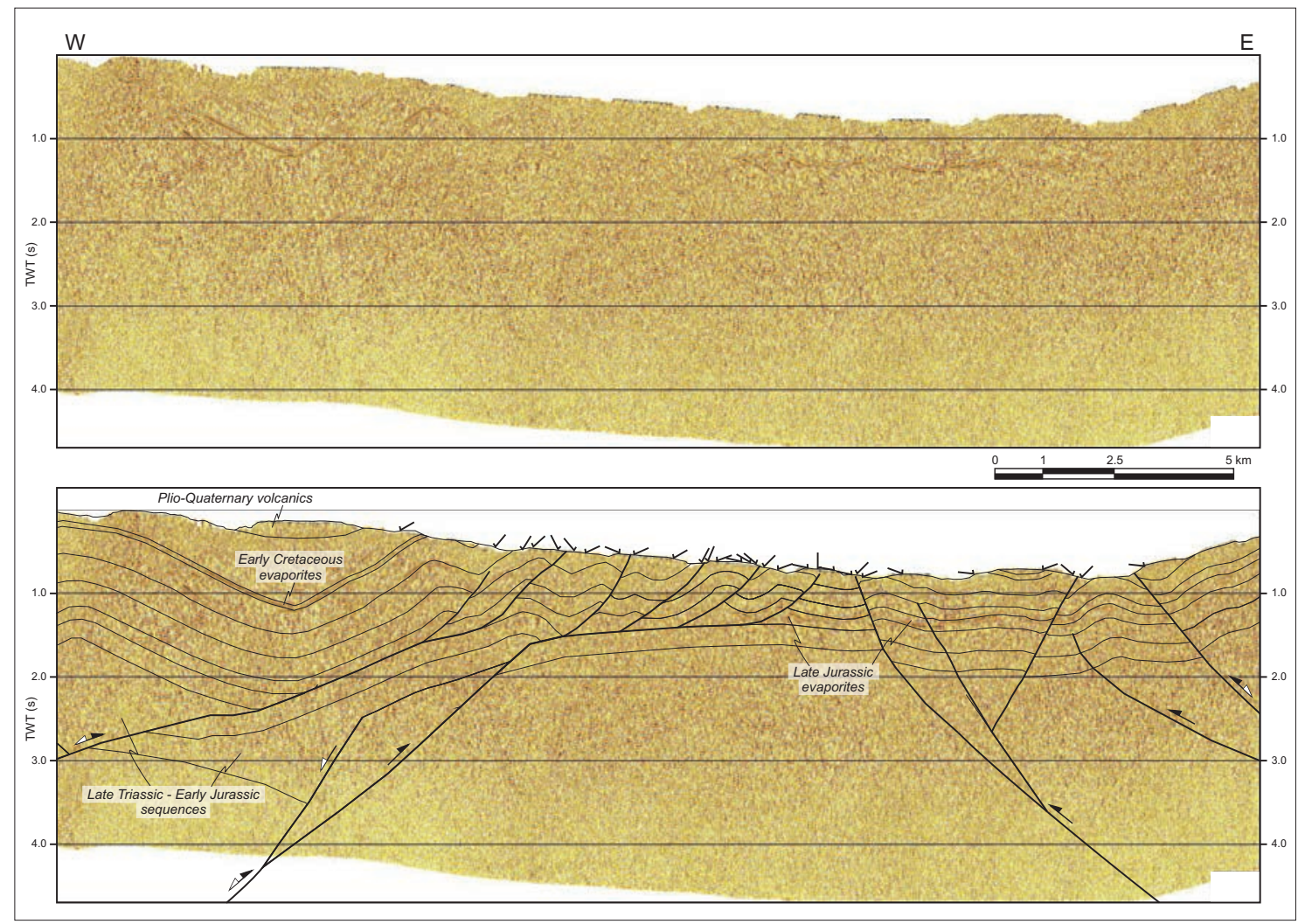

FIG. 8. Above: migrated seismic line; below: interpreted seismic line and structures identified at surface. Three domains can be identified, from west to east: A broad syncline where Upper Cretaceous sequences are hosted, controlled by the insertion of a Permian to Upper Triassic basement wedge at depth; a sector where basement shortening is transferred to the sedimentary cover over an Upper Jurassic evaporitic decollement (Fig. 5); and finally a series of backthrusts rooted into the basement corresponding to the western flank of the Sierra Azul anticline (Fig. 6) (location in figure 7).

that are piled over a nearly horizontal decollement characterized by its high reflectivity, assigned to the Upper Jurassic evaporites. Finally iii. a third sector is characterized by west-vergent structures with intermediate wave-lengths rooted into the basement. Therefore a triangle zone is defined between this last sector and the previous fan of east-verging structures.

Migrated reflection seismic section of figure 9 shows an improved acquisition quality respect to figure 8. Here reflectors can be more clearly assigned to key stratigraphic levels, based on their relative reflectivity. Again as in the previous seismic line, this section shows three distinctive sectors that from west to east are: i. A broad syncline (Portezuelos Colorados syncline) highlighted by two reflectors corresponding to the Lower Cretaceous and Upper Jurassic evaporites respectively. This structure has an asymmetric geometry with an east-vergence
(Fig. 9). Two structural levels can be recognized in this western section. An upper one, where Jurassic to Cretaceous beds are folded into a syncline, and a lower section, where horizons are gently dipping homogeneously to the west. Those are interpreted as a Late Triassic synrift sequence, whose geometry depicts an east-growing wedge that abruptly vanishes in a noisy sector (Fig. 9). To the east, the sedimentary cover is composed of west-dipping fault bounded anticlines of short wave-lengths and amplitudes. Finally a third-eastern section is recognized, where west-verging structures, rooted beneath the Late Jurassic cover bound a triangle zone respect to the previous section.

In a more detailed view, the Portezuelos Colorados syncline (Fig. 10; for location see figure 9) shows Late Cretaceous sedimentary successions with onlapping relations at its flanks. This results 


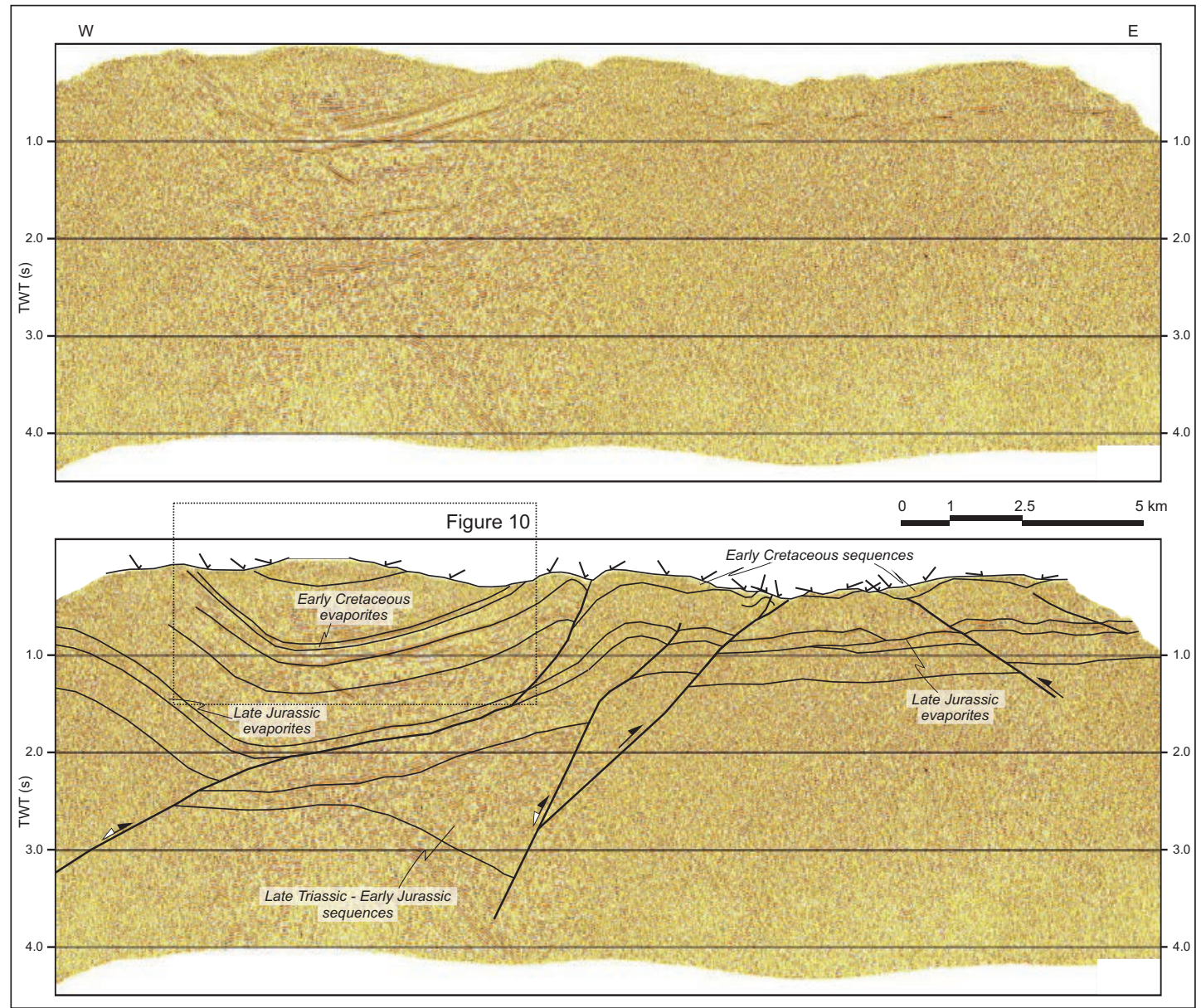

FIG. 9. Above: migrated seismic line; below: interpreted seismic line and structures identified at surface. The three domains identified in figure 8 were also recognized in this section. Note a better development of the Late Triassic to Early Jurassic synrift wedge, with respect to the previous described line, below the area of shallow deformation. See figure 7 for location in map view.

in a progressive wedging of the units that are filling the syncline core towards both edges.

These units have been related at this locality to synorogenic strata based on the presence of Early Jurassic to Late Cretaceous detrital zircon populations (Fig. 10), which implies coetaneous exhumation of the Andes, where Mesozoic arc roots are exposed (Tunik et al., 2010). Late Cretaceous sequences are unconformably overlaid by Late Oligocene to Lower Miocene sequences of the Palaoco Formation as revealed from seismic and field data (Fig. 10).

The seismic line displayed in figure 11 (see figure 7 for location) is located at the eastern flank of Sierra Azul anticline. This clearly shows an east-vergent deformational front. In this view, a series of structural features corresponding to i. the east-dipping limb of the Sierra Azul anticline, ii. a frontal syncline and iii. a series of west-dipping fault splays can be distinguished. The last two are interpreted in figure 11 as the products of the transfer of shortening from the Sierra Azul basement structure to the east, into the sedimentary cover. The major anticline frontal limb steepens progressively towards the emergent main fault, indicating a clear east-vergence for the whole structure. This feature is uplifted by an inferred west dipping reverse fault, rooted into the basement that propagates beneath a broad symmetrical syncline (Quechuvil syncline) where proximal Upper Miocene sequences were accumulated (Fig. 11). 


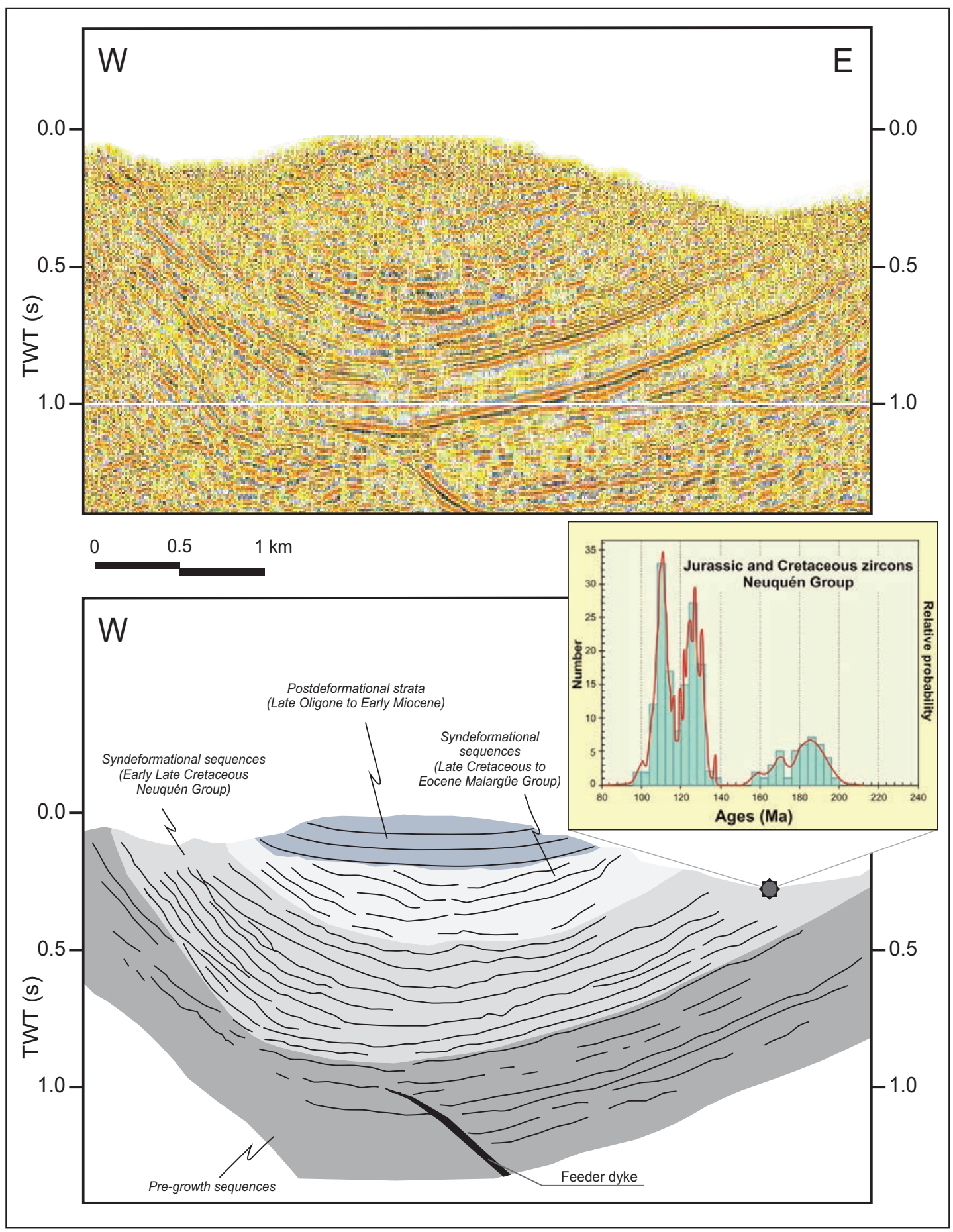

FIG. 10. Close look to the Portezuelos Colorados syncline (westernmost sector of seismic line displayed in figure 9). The Upper Cretaceous syncline fill shows onlapping reflector terminations onto the fold flanks. These were recently interpreted as synorogenic deposits (see text for further details). Note that Upper Oligocene to Miocene volcanic beds are unconformably covering the folded structure. U-Pb ages of detrital zircons at the Late Cretaceous syncline core on the upper right corner were taken from Tunik et al. (2010). 


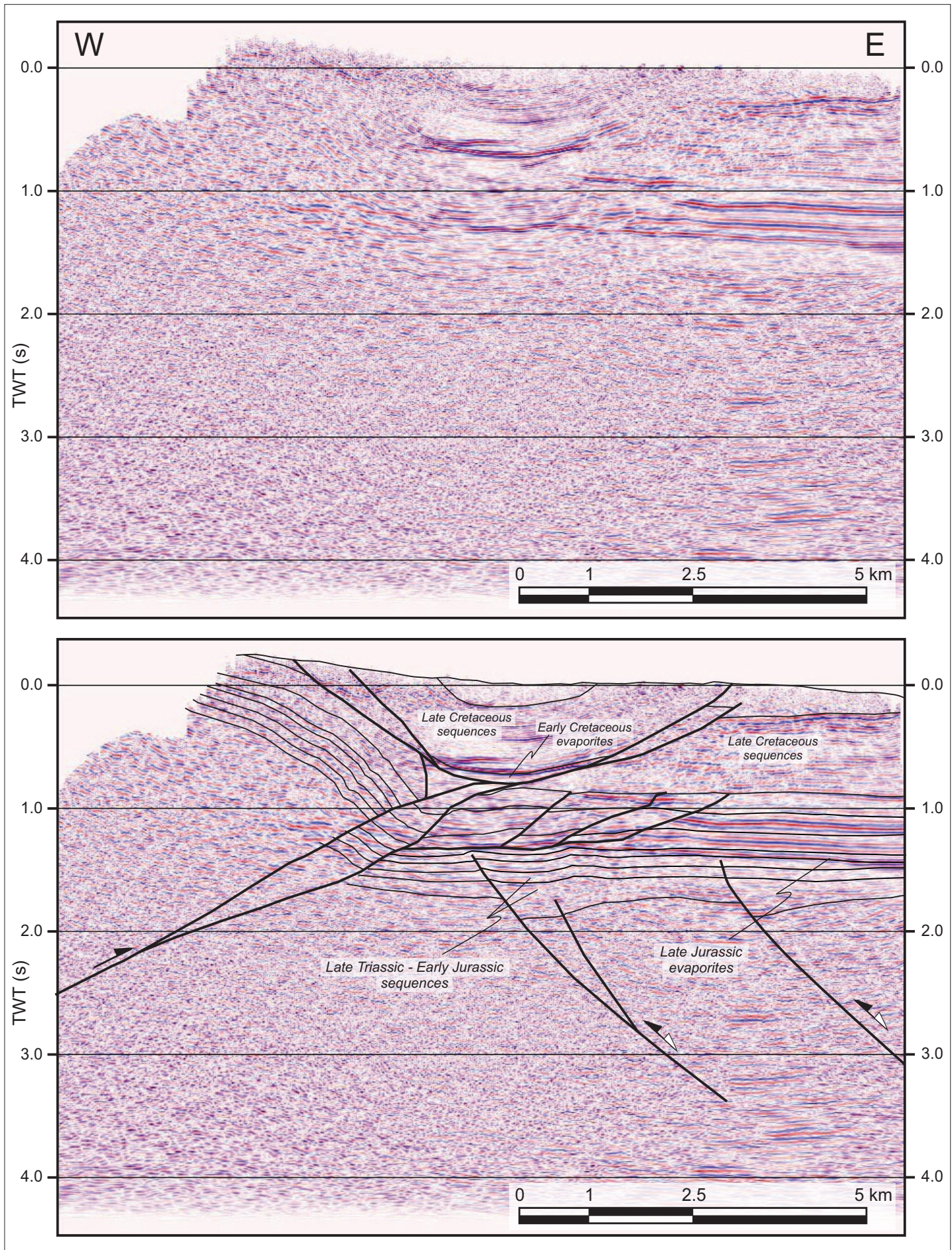

FIG. 11. Seismic reflection profile and interpretation that crosses the eastern flank of Sierra Azul anticline at the emergent orogenic front (see figure 7 for location). Basement contractional structures are inserted in Upper Jurassic evaporites beneath the Late Miocene foreland basin. A detailed view reveals two stages of contractional deformation: first, where basement shortening was transferred to the Jurassic-Cretaceous cover, and a later one where basement structures cut the thin-skinned domain cannibalizing the westernmost foreland basin. 
High reflectivity of Upper Cretaceous evaporitic units is recognized at the syncline limbs, which implies a Upper Cretaceous to Neogene sedimentary infill at its core (Fig. 11), constrained by surficial data. At this section, the Quechuvil syncline has its maximum areal development, whereas to the north and south gets narrower and more asymmetrical, ending as a fault-bounded monoclinal ramp. This syncline is detached from the Lower Cretaceous evaporites by a backthrust and by an east-verging fault that splays upwardly into two faults, an emergent and a blind thrust that vanishes into the Neogene cover (Fig. 11).

Beneath the Quechuvil syncline, the lower Mesozoic sedimentary units are highly deformed forming three duplexes detached in Upper Jurassic evaporites and Lower Cretaceous sedimentary successions. This deeper and relatively higher shortening is transferred to the basement to the west by a west dipping fault associated with a splay from the major Sierra Azul thrust (Fig. 11).

Other recognized features are two half-grabens controlled by east-dipping normal faults that accommodate Upper Triassic to Lower Jurassic synrift deposits east of the Sierra Azul uplift (Fig. 11). These successions are characterized by their high opacity (Fig. 11). The westernmost half-graben is inverted affecting up the Upper Jurassic packages, while the eastern half-graben is only mildly inverted, as noticed by an upwardly convex shape in the cover.

\section{Construction of the structural cross-section}

A structural cross section with a total extent of 60 $\mathrm{km}$ was constructed over the eastern main Andean slope. This integrates all the available information from the eastern slope of Sierra Azul to the drainage divide area (see figures 7 and 12 for location). For the balancing and modelling of this cross section, the software 2DMOVE 2009.1 (C Midland Valley Exploration Ltd.) was used. The balancing techniques were done taking into account surface structural data and seismic and borehole data as constraints. For its restoration we used a flexural slip unfold algorithm that allows to maintain the variable thickness of the platform Jurassic and Cretaceous units, as well as of the Late Triassic wedge like depocentres, when openly folded, while a line length unfold algorithm was used for minor structures detached from sedimentary levels. This balanced cross sec- tion delimited to the Main Andes was integrated to the one adjacent made by Giambiagi et al. (2009) comprising the easternmost part of Malargüe FTB and its deformational front (Fig.12).

\section{Discussion and conclusions}

A regional cross section from the drainage divide to the foreland area (Fig. 12) was done in order to identify the different deformational fronts that constructed the Andes at $36^{\circ} \mathrm{S}$ through time, and their relation to contemporaneous foreland basins. The Portezuelos Colorados syncline (Figs. 8, 9 and 10) was probably part of a depocenter associated with a Late Cretaceous foreland wedge top, indicating that structures west of it were likely remnants of the Late Cretaceous orogenic belt. This is assumed due to the identification of syngrowth strata in Upper Cretaceous sections at its limbs (Fig. 10). These sections had been related to synorogenic sedimentation based on their U-Pb detrital content (see Geological Setting; Tunik et al., 2010). The Late Cretaceous foreland basin would have been discontinuously developed/preserved east of this structure (Figs. 12, 13 and 14). Contrastingly, the Late Miocene foreland basin has a good development east of the Sierra Azul anticline (Figs. 12 and 14). Assuming that the main Neogene contractional front would be located at the Sierra Azul, the hinterland zone west of it would have remain basically fossilized from a contractional point of view (Fig. 14). The unconformable development of Upper Oligocene to Miocene volcanic piles on top of the Mesozoic deformed sequences in the hinterland shows that a pre-Oligocene contraction affected this area (Figs. 4 and 10). However, minor reactivation of some local structures is observable due to folding of Cenozoic strata in this area. The Sierra Azul itself is associated with strong deformation of Upper Miocene strata (Fig. 11) in the Quechuvil syncline. In this context the hinterland zone to the west would have eastwardly shifted more or less rigidly respect to the Neogene orogenic front in the Sierra Azul.

The structural characterization of this section corresponding to the Malargüe FTB can be detailed by means of a balanced cross section between the drainage divide area and the emergent orogenic front next to the Quechuvil syncline at Río Grande area (Fig. 13). The whole section, summing the different contractional stages that affected the region accom- 
modated a total shortening of $11.3 \mathrm{~km}$ over the main Andean sector (Fig. 13). As identified from surficial and subsurface information this region presents a set of structural domains characterized by particular constructional mechanisms that acted at different times (Fig. 14). The westernmost section is characterized by intermediate to long wave-lenght structures formed by the tectonic inversion of Late Triassic structures locally detached at Upper Jurassic evaporites. Some structures in this section are also generated by the insertion of basement wedges associated with inversion of Late Triassic structures as depicted in figure 13. Reactivation of normal faults seems to be selective, being some Late Triassic halfgrabens bypassed by contractional deformation, maintaining almost their original extensional geometry. Examples can be found beneath the Portezuelos Colorados syncline, and to the east of Sierra Azul beneath the Quechuvil syncline, where two halfgrabens are mildly inverted. These combined mechanisms at the westernmost section acted in Late Cretaceous times, forming a foreland basin east of the Portezuelos Colorados location.

The next sector to the east is formed by an east-verging thin-skinned domain detached in Upper Jurassic evaporites. Here the basement behaves as a rigid lid. Eastern Late Triassic halfgrabens depicted in figure 13 are inserted into the sedimentary column over that lid, forming this thin-skinned deformation as seen in the seismic section (Fig. 8). This deformation is post-Late Cretaceous in age based on the cannibalization of the previous foreland basin. To the east, this fan of thin-skinned deformation is suddenly interrupted by a series of west-vergent basement structures associated with tectonic inversion of the Sierra Azul Late Triassic depocenter (Fig. 13).

Finally, the eastern Sierra Azul flank shows to be a Neogene uplift, constrained by the age (18 Ma; Silvestro and Atencio, 2009) of the youngest deformed sequences. This structure is not associated with tectonic inversion, such as to the west, but to relatively low angle basement faults (Fig. 14).

As a preliminary conclusion it can be stated that there are at least two clear contractional phases that differ in mechanisms: i. the westernmost sector has been formed by tectonic inversion plus associated thin-skinned deformation in Late Cretaceous times; while ii. the eastern sector was constructed in Late Miocene times by primary basement faults, associated also with thin-skinned deformation.

Therefore, different orogenic processes can be clearly separated in space and time, pointing to the questions $\mathbf{i}$. why the upper crust have experimented variable mechanisms of deformation through time and ii. why the upper crust was selective in yielding through previous anisotropies or brittleductile transitions that created primary basement faults. Weakness zones, where contraction was accommodated, varied through time: While during Late Cretaceous times the anisotropies that absorbed shortening corresponded to the Late Triassic rift system, in Late Miocene times brittleductile transitions seem to have developed having that role. Brittle-ductile transitions develop when the crustal thermal structure changes due to an increase in thermal gradient or as a function of time. Then structural styles through time at the Malargüe FTB could have varied and produced by a modification in the thermal state, passing from a rather cold crustal setting in Late Cretaceous times to a relatively hotter one in Late Miocene times. This thermal state could have been controlled by the different arc expansions registered in the area. As indicated, a shallow subduction regime was proposed for the Late Miocene time. While in Late Cretaceous times the arc remained at the Present western Chilean slope at these latitudes, leaving a cold foreland sector behind. Subsequently, during the Late Miocene the arc expanded more than $500 \mathrm{~km}$ away from the trench modifying the thermal state of the crust (Fig. 15). Therefore, variable thermal state and consequently structural styles could have been the product of variable subduction geometry. This situation is seen in the Present Pampean flat-slab segment where deformation followed the expansion of the arc magmatism through thermal weakening of the crust (Ramos et al., 2002).

The inner sector of the Malargüe FTB is the product of tectonic inversion in Late Cretaceous times, probably in a rather cold setting, at the time when the arc front remained to the west. The Present orogenic front, represented by the Sierra Azul uplift was formed by primary contractional basement structures developed in Late Miocene time. They were detached from brittle-ductile transitions when the crustal thermal state had changed due to the eastward expansion of the arc at that time. 


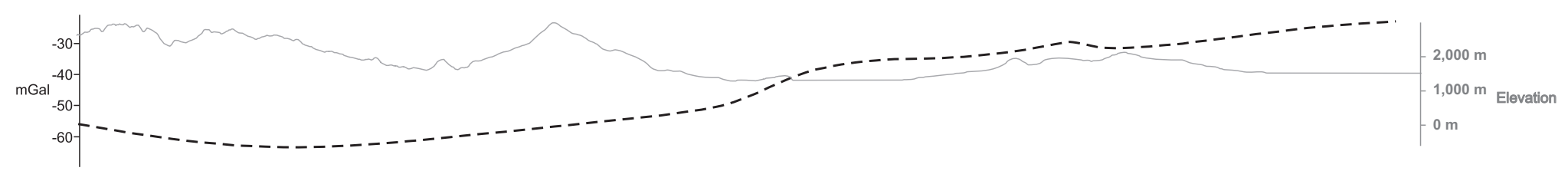

$129 \mathrm{~km}$

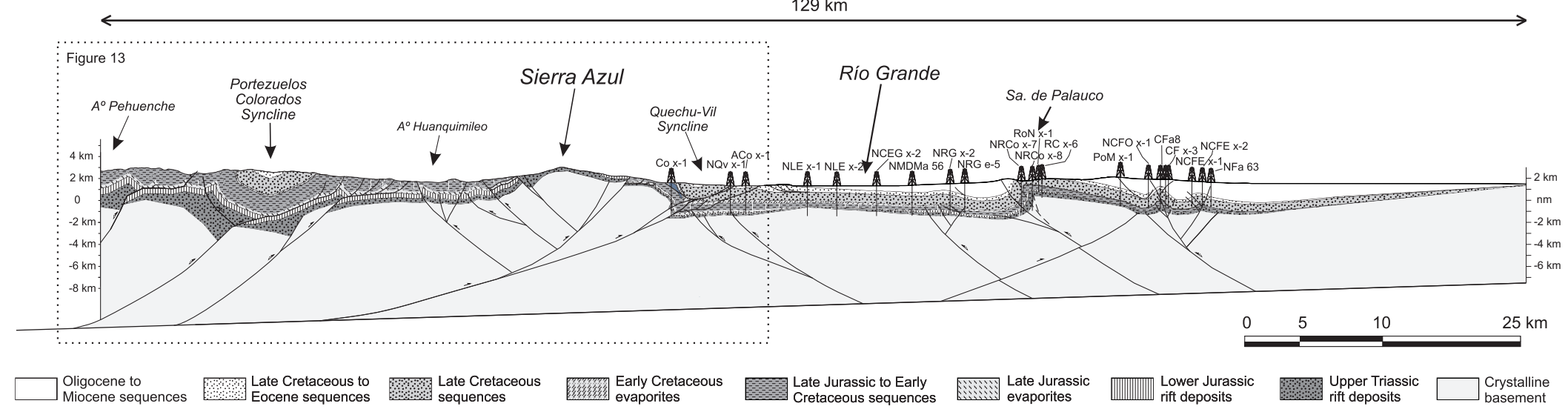

FIG. 12. Regional structural section based on field, bore-hole and seismic data from the westernmost sections, described in the present work (Figs. 7 and 8 ), to the foreland area (the easternmost sector is modified from Giambiagi et al., 2009)(location in figure 3). Residual gravity anomaly (upper dashed line) has been represented for comparison, together with exaggerated 2D topography. Note major gravity gradients associated with basement thrust fronts, with the exception of the Sierra Azul anticline probably hidden by negative contrasts associated with thick Upper Triassic synrift packages. Note finally the development of the Late Miocene basin to the east of the eastern flank of the Sierra Azul. 
$60 \mathrm{~km}$
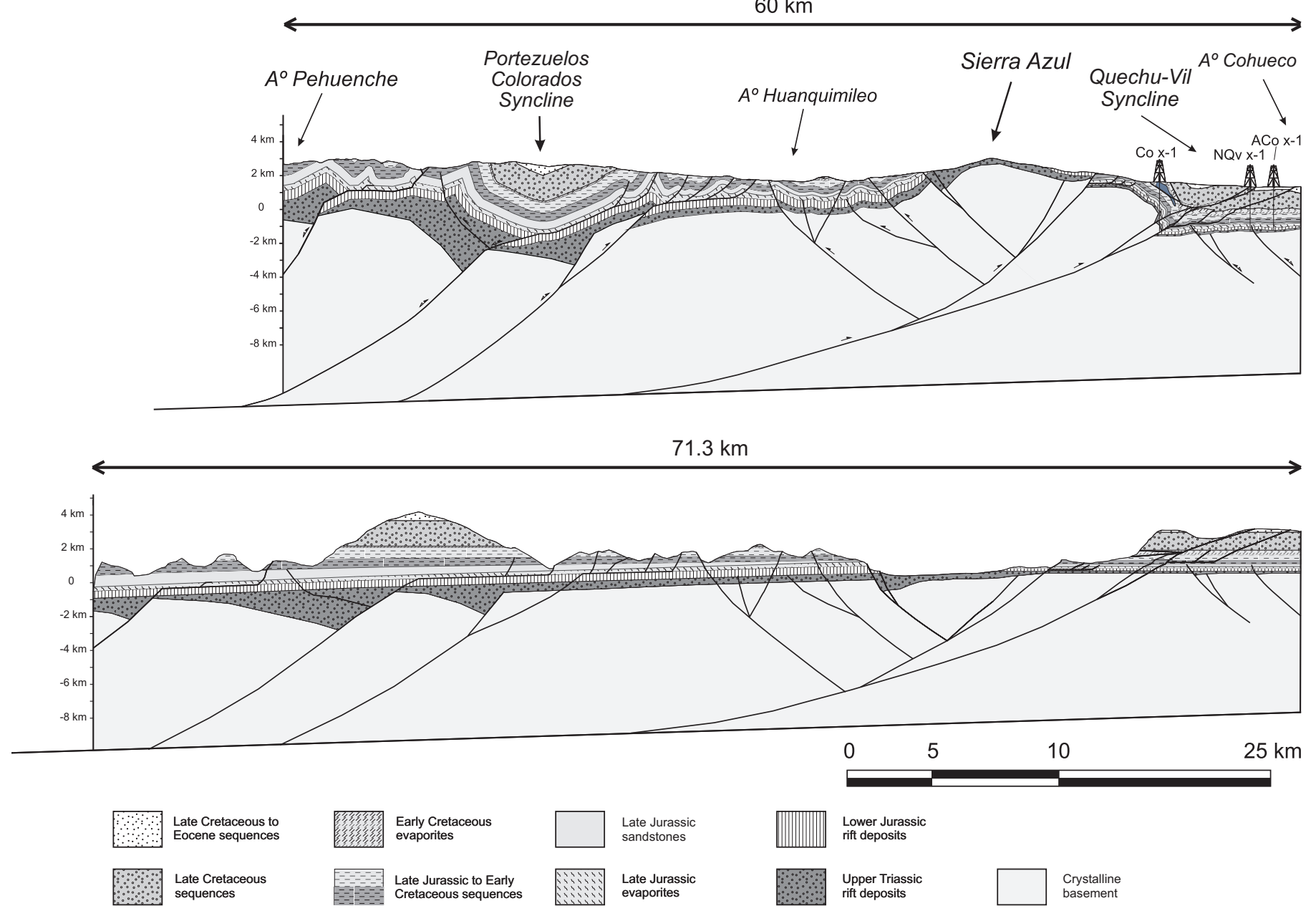

FIG. 13. Structural cross section corresponding to the westernmost sector of figure 12 at the eastern slope of the Andes. An internal domain of basement structures inserted in Jurassic to Cretaceous sedimentary sections, is interpreted as the product of inversion of Late Triassic half-grabens. These half-grabens are identified in seismic data. The series of backthrusts associated with the western slope of the Sierra Azul are also interpreted as associated with inversion of normal structures of Late Triassic age, based on anomalous thicknesses at the hanging walls. On the contrary, the eastern slope of the Sierra Azul is formed by basement structures not linked to reactivated anisotropies such as in the previous case. 


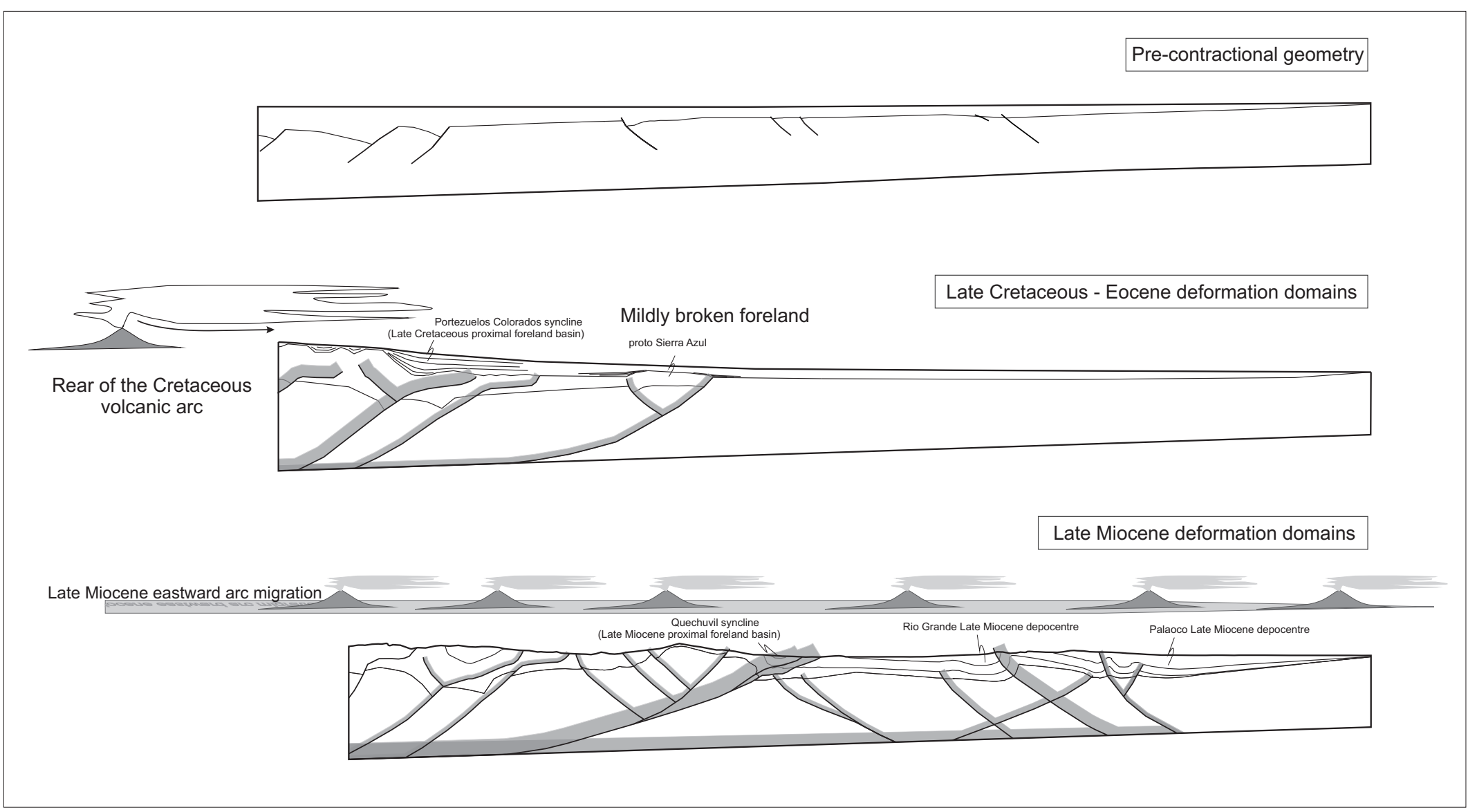

FIG. 14. Main deformational events discussed through the text and relative arc positions. Active structures for each setting are indicated by thick grey lines. In this model when arc remained on the west during Late Cretaceous, the retroarc zone yielded through previous anisotropies (Late Triassic extensional detachment). Contrastingly, when the arc expanded to the east as proposed for the Late Miocene, the thermal structure changed and the crust yielded through fragile-ductile transitions that reached the eastern retroarc area. 


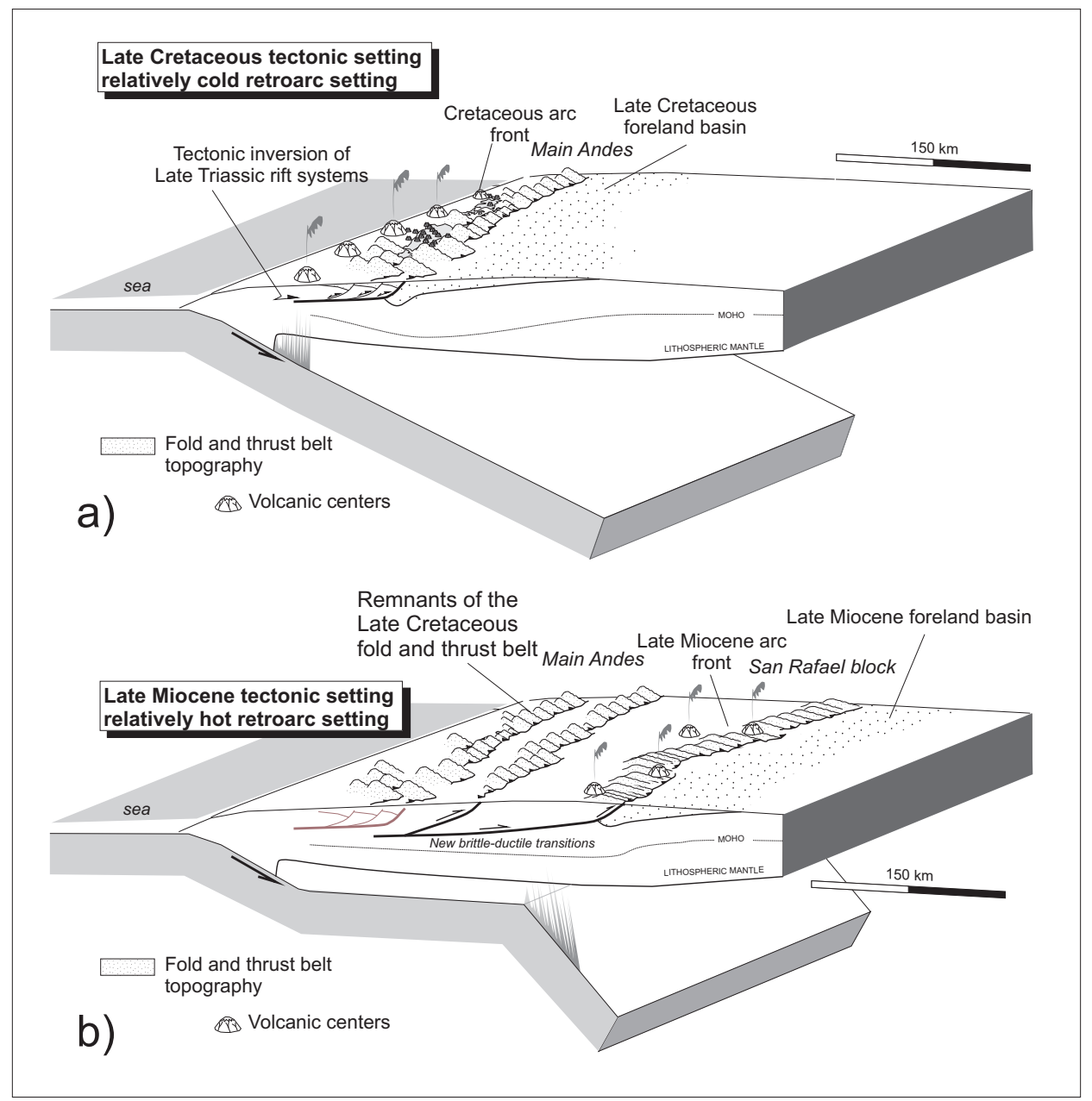

FIG. 15. Cartoons showing both Late Cretaceous and Late Miocene contractional stages. a. Basement structures interpreted from seismic and field data are associated with Late Cretaceous synorogenic strata and are circumscribed to the westernmost sector of the study region. These are interpreted as the product of inversion of previous anisotropies linked to Late Triassic extensional faults. During this time the arc remained at the hinterland zone mostly preserved at the Present western slope of the Andes; b. Easternmost basement structures are interpreted as primarily formed and not associated with the inversion of Mesozoic extensional troughs in the area. During this time the arc expanded to the east and Late Miocene foreland basins were formed. Finally, thermal effects associated with the arc expansion in the foreland are invoked to explain development of brittle-ductile transitions that originated basement structures in Late Miocene times. During the previous contractional stage the retroarc zone was probably characterized by a low thermal flux, reason by which basement structures would have only used previous anisotropies.

\section{Acknowledgements}

The authors would like to thank C. Arriagada and M. Suárez for publishing the article in this Special Issue on Andean Geology. This work has been financed with the following grants: PIP 112-200801-00016 and 2010-2012. UBACyT. We also thank the comments of the reviewers Drs. M. Farías and A. Tassara that helped very much to improve and clarify the manuscript. We are grateful to Midland Valley Ltd. for providing us with Academic Licenses of the Move ${ }^{\circledR}$ Software This is the contribution R-49 of the Instituto de Estudios Andinos Don Pablo Groeber.

\section{References}

Bechis, F. 2009. Deformación transtensiva de la cuenca Neuquina: análisis a partir de ejemplos de campo y modelos análogos. Ph.D. Thesis (Unpublished), Universidad de Buenos Aires: 258 p. 
Bermúdez, A.; Delpino, D.; Frey, F.; Saal, A. 1993. Los basaltos de retroarco extraandinos. In Geología y Recursos Naturales de Mendoza (Ramos, V.A.; editor). In Congreso Geológico Argentino No. 12 y Congreso de Exploración de Hidrocarburos No. 2. Asociación Geológica Argentina e Instituto Argentino de Petróleo, Relatorio: 173-195. Buenos Aires.

Bettini, F.H.; Legarreta, L.; Kozlowski, E. 1979. Corte Estructural $\mathrm{C}^{\circ}$ Campanario-Río Potimalal. Comisión Geológica No. 5. Yacimientos Petrolíferos Fiscales (Unpublished). Argentina.

Bettini, F.; Pombo, R.; Mombru, C.; Uliana, M. 1978. Consideraciones sobre el diastrofismo andino en la vertiente oriental de la Cordillera Principal, entre los $34^{\circ} 30^{\prime}$ y los $37^{\circ}$ de latitud sur. In Congreso Geológico Argentino, No. 7, Actas 1: 671-683. Buenos Aires.

Blakely, R.J. 1995. Potential theory in gravity and magnetic applications. Cambridge University Press: 441 p. United Kingdom.

Briggs, I.C.1974. Machine contouring using minimum curvature. Geophysics 39 (1): 39-48.

Charrier, R.; Pinto, L.; Rodríguez, M.P. 2007. Tectonostratigraphic evolution of the Andean orogen in Chile. In The Geology of Chile. (Moreno, T.; Gibbons, W.; editors). The Geological Society: 21-114. London.

Dimieri, L. 1997. Tectonic wedge geometry at Bardas Blancas, southern Andes (36 ${ }^{\circ}$ ), Argentina. Journal of Structural Geology 19 (11): 1419-1422.

Galarza, B.; Valcarce, G.Z.; Folguera, A.; Bottesi, G.L. 2009. Geología y evolución tectónica del frente cordillerano a los 36³0'S: bloques de Yihuin-Huaca y Puntilla de Huincán. Mendoza. Revista de la Asociación Geológica Argentina 65 (1): 170-191.

Giambiagi, L.; Ghiglione, M.; Cristallini, E.; Bottesi, G. 2009. Características estructurales del sector sur de la faja plegada y corrida de Malargüe $\left(35^{\circ}-36^{\circ}\right)$ : Distribución del acortamiento e influencia de estructuras previas. Revista de la Asociación Geológica Argentina 65 (1): 140-153.

Hinze, W.J. 2003. Bouguer reduction density, why 2.67? Geophysics 68 (5): 1559-1560.

James, D.E.; Sacks, S. 1999. Cenozoic formation of the Central Andes: A geophysical perspective. In Geology and Mineral Deposits of Central Andes (Skinner, B.; editor) Society of Economic Geology, Special Publication 7: 1-25. London.

Jordan, L; Burns, M.; Veiga, R.; Pángaro, F.; Copeland, P.; Kelley, S.; Mpodozis, C. 2001. Extension and basin formation in the southern Andes caused by increased convergence rate: A mid-Cenozoic trigger for the Andes. Tectonics 20 (3): 308-324.
Kane, M.F. 1962. A comprehensive system of terrain corrections using a digital computer. Geophysics: 27 (4): 455-462.

Kay, S.M.; Burns, M.; Copeland, P.; Mancilla, O. 2006. Upper Cretaceous to Holocene magmatism and evidence for transient Miocene shallowing of the Andean subduction zone under the northern Neuquén Basin. In Evolution of an Andean margin: A tectonic and magmatic view from the Andes to the Neuquén Basin (35-39º lat.) (Kay, S.M.; Ramos, V.A.; editors). Geological Society of America, Special Paper 407: 19-60. doi: 10.1130/2006.2407(02).

Kay, S.M.; Godoy, E.; Kurtz, A. 2005. Episodic arc migration, crustal thickening, subduction erosion, and magmatism in the south-central Andes. Geological Society of America Bulletin 117: 67-88.

Kozlowski, E.N. 2008. Geología de la región al este del paso Pehuenche. provincia de Mendoza. Trabajo Final de Licenciatura (Unpublished). Universidad de Buenos Aires: 125 p.

Kozlowski, E.; Manceda, R.; Ramos, V. A. 1993. Estructura. In Geología y Recursos Naturales de Mendoza (Ramos, V.A.; editor). Congreso Geológico Argentino, No. 12 y Congreso de Exploración de Hidrocarburos, No. 2. Asociación Geológica Argentina e Instituto Argentino de Petróleo, Relatorio: 235-256. Buenos Aires.

Litvak, V.; Folguera, A.; Ramos, V.A. 2008. Determination of an arc-related signature in late Miocene volcanism over the San Rafael Block, Southern Central Andres $\left(34^{\circ} 30^{\prime \prime}-37^{\circ}\right.$ ) Argentina: The Payenia shallow subduction zone. In International Symposium on Andean Geodynamics, No 7, Extended abstracts: 289-291. Nice. France.

Manceda, R.; Figueroa, D. 1995. Inversion of the Mesozoic Neuquen rift in the Malargue fold and thrust belt, Mendoza, Argentina. In Petroleum basins of South America. (Tankard, A.J.; Suárez S., R.; Welsink, H.J.; editors). American Association of Petroleum Geologists. Memoir 62: 369-382. Tulsa.

Mosquera, A.; Ramos, V.A. 2006. Intraplate deformation in the Neuquén Embayment. In Evolution of an Andean margin: A tectonic and magmatic view from the Andes to the Neuquén Basin $\left(35^{\circ}-39^{\circ} \mathrm{S}\right.$ lat.) (Kay, S.M.; Ramos, V.A.; editors). Geological Society of America, Special Paper 407: 97-123. doi: 10.1130/2006.2407(05).

Mpodozis, C.; Ramos, V.A. 2008. Tectónica jurásica en Argentina y Chile: extensión, subducción oblicua, rifting, deriva y colisiones? Revista de la Asociación Geológica Argentina 63 (4): 481-497. 
Nagy, D. 1966. The gravitational attraction of a right rectangular prism: Geophysics 31 (2): 362-371.

Nocioni, A. 1996. Estudio Estructural de la Faja Plegada y Corrida de la Cuenca Neuquina Surmendocina (35³0' y $37^{\circ} 30^{\prime}$ Latitud sur). In Congreso Geológico Argentino No. 13 y Congreso de Exploración de Hidrocarburos No. 3, Actas 2: 353-372. Buenos Aires.

Nullo, F.E.; Stephens, A.; Otamendi, J.; Baldauf, P. 2002. El volcanismo del Terciario superior del Sur de Mendoza. Revista de la Asociación Geológica Argentina 57 (2): 119-132.

Orts, D.L. 2009. Geología de la región comprendida entre el cerro Rucamileo y el arroyo Potimalal. Tesis de Licenciatura (Unpublished). Universidad de Buenos Aires: 93 p.

Orts, S.; Ramos, V.A. 2006. Evidence of middle to late Cretaceous compressive deformation in the high Andes of Mendoza, Argentina. Backbone of the Americas. Abstract with Programs 5: p. 65. Mendoza.

Quintana, A.L. 2008. Geología de la sierra Azul. Provincia de Mendoza. Trabajo Final de Licenciatura (Unpublished). Universidad de Buenos Aires: 132 p.

Radic, J.P. 2010. Las cuencas cenozoicas y su control en el volcanismo de los complejos Nevados de Chillán y Copahue-Callaqui (36-395). Andean Geology 37 (1): 220-246.

Radic, J.P.; Rojas, L.; Carpinelli, A.; Zurita, E. 2002. Evolución tectónica de la cuenca terciaria de Cura-Mallín, región cordillerana chileno argentina (36³0’3900’S). In Congreso Geológico Argentino, No.15, Actas 3: 233-237. Calafate.

Ramos, V.A. 1989 . The birth of Southern South America. American Scientist 77 (5): 444-450.

Ramos, V.A.; Cristallini, E.O.; Pérez, D.J. 2002. The Pampean flat-slab of the Central Andes. Journal of South American Earth Sciences 15: 59-78.

Silvestro, J.; Atencio, M. 2009. La cuenca cenozoica del Río Grande y Palauco: edad, evolución y control estructural. Faja plegada de Malargüe ( $\left.36^{\circ} \mathrm{S}\right)$. Revista de la Asociación Geológica Argentina 65 (1): 154-169.

Somoza, R. 1998. Updated Nazca (Farallon)-South América relative motions during the last $40 \mathrm{My}$ : implications for mountain building in the central Andean Región. Journal of South American Earth Sciences 11 (3): 211-215.

Somoza, R.; Zaffarana, C.B. 2008. Mid-Cretaceous polar standstill of South America, motion of the Atlantic hotspots and the birth of the Andean cordillera. Earth and Planetary Science Letters 271: 267-277.
Spagnuolo, M.; Litvak, V.; Folguera, A.; Bottesi, G.; Ramos, V.A. 2011. In Press. Neogene magmatic expansion and mountain building processes at the southern Central Andes, $36^{\circ}-37^{\circ} \mathrm{S}$, Argentina. Journal of Geodynamics.

Spagnuolo, M.G.; Folguera, A.; Ramos, V.A. 2008. Linkage between Neogene arc expansion and contractional reactivation of a Cretaceous fold-and-thrust belt (southern Central Andes, $36^{\circ}-37^{\circ} \mathrm{S}$ ). In International Symposium on Andean Geodynamics, No. 7, Extended Abstracts: 513-516. Niza. Francia.

Spikings, R.; Dungan, M.; Foeken, J.; Cárter, A.; Page, L.; Stuart, F. 2008. Tectonic response of the central Chilean margin $\left(35-38^{\circ} \mathrm{S}\right)$ to the collision and subduction of heterogeneous oceanic crust: a thermochronological study. Journal of the Geological Society of London 165 (5): 941-953.

Stern, C. 2004. Active Andean volcanism: Its geologic and tectonic setting. Revista Geológica de Chile 31 (2): 161-206.

Suárez, M.; Emparan, C. 1995. The stratigraphy, geochronology and paleophysiography of a Miocene freshwater interarc basin, Southern Chile. Journal of South American Earth Sciences 8 (1): 17-31.

Tunik, M.; Folguera, A.; Naipauer, M.; Pimentel, M.; Ramos, V.A. 2010. Early uplift and orogenic deformation in the Neuquén Basin: Constraints on the Andean uplift from U-Pb and Hf isotopic data of detrital zircons. Tectonophysics 489 (1-4): 258-273.

Turienzo, M.M. 2010.Structural style of the Malargüe fold-and-thrust belt at the Diamante River area (34³0'-3450'S) and its linkage with the Cordillera Frontal, Andes of central Argentina. Journal of South American Earth Sciences 29 (3): 537-556.

Turienzo, M.M. 2009. La estructura de la faja corrida y plegada de Malargüe en la zona del río Diamante

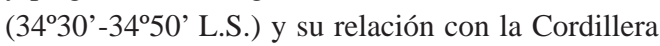
Frontal, provincia de Mendoza. Revista de la Asociación Geológica Argentina 65 (1): 123-139.

Yagupsky, D.; Cristallini, E.; Fantín, J.; Valcarce, G.; Bottesi, G.; Varadé, R. 2008. Oblique half-graben inversion of the Mesozoic Neuquén Rift in the Malargüe Fold and Thrust Belt, Mendoza, Argentina: New insights from analogue models. Journal of Structural Geology 30 (7): 839-853. doi: 10.1016/j.jsg.2008.03.007.

Zapata, T.R.; Brissón, I.; Dzelalija, F. 1999. La estructura de la faja plegada y corrida andina en relación con el control del basamento de la cuenca Neuquina. Boletín de Informaciones Petroleras 60 (2): 112-121. 